\title{
Differences in absconding between African and European honeybee subspecies facilitate invasion success of small hive beetles
}

\author{
Peter NeumanN ${ }^{1,2}$, Sebastian SpiewoK ${ }^{3}$, Jeff Pettis ${ }^{1,4}$, Sarah E. RadlofF ${ }^{5}$, \\ Robert SPOONER-HART ${ }^{6}$, Randall HEPBURN ${ }^{2}$

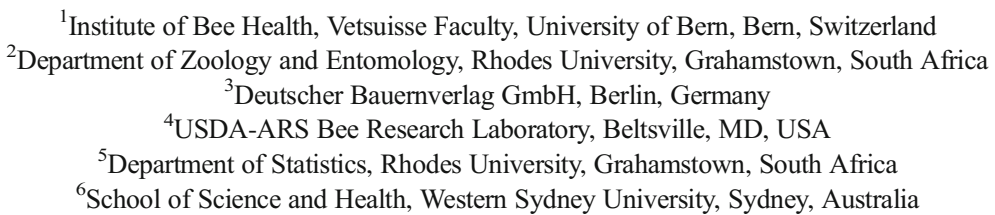

Received 7 February 2017 - Revised 13 February 2018 - Accepted 26 April 2018

\begin{abstract}
Small hive beetle (SHB) is an invasive species in populations of European honeybee subspecies, but underlying reasons for SHB success are not well understood. African and European honeybee, Apis mellifera, subspecies differ in absconding, and small hive beetle, greater wax moth (GWM) and ants all can exploit abandoned nests. However, the impact of host absconding on SHB reproduction and the role of GWM and ants as competitors are not known. Here, we conducted a survey in South Africa, Australia and the USA to evaluate SHB and GWM reproduction and foraging by ants in abandoned honeybee colonies. While the impact of competing ants and GWM was not significant, the data show higher SHB reproduction in abandoned nests of European honeybees compared to African ones, but less for GWM. The positive correlation between abandoned protein sources (brood, pollen) on SHB reproduction suggests that the less efficient preparation for absconding by European honeybee subspecies combined with their large colony sizes is a key factor for the invasion success of SHB.
\end{abstract}

ants / Apis mellifera / Aethina tumida / Galleria mellonella / small hive beetle

\section{INTRODUCTION}

Small hive beetle, Aethina tumida Murray (Coleoptera: Nitidulidae; = SHB), is native to subSaharan Africa (Hepburn and Radloff 1998; Neumann and Ellis 2008) and can reproduce in association with honeybees, Apis mellifera (Lundie 1940), bumblebees (Spiewok and

Corresponding author: P. Neumann,

p.neumann@vetsuisse.unibe.ch

Sadly, H. Randall Hepburn passed away on 15 October 2014 in Nelspruit, Mpumalanga, South Africa. This paper is dedicated in his memory.

Manuscript editor: Yves Le Conte
Neumann 2006a), stingless bees (Greco et al. 2010; Peña et al. 2014; Spooner-Hart et al. 2017), fruits (Ellis et al. 2002) and meat (Buchholz et al. 2008). SHB has recently become an invasive species and introductions have been recorded from America, Australia, Europe and Asia since 1996 (Neumann et al. 2016). While SHBs are usually a minor pest in their endemic range (Lundie 1940; Pirk and Yusuf 2017), they can cause considerable damage to honeybee colonies in their new ranges (Neumann and Elzen 2004; Neumann et al. 2016; Spooner-Hart et al. 2017). Since damage to honeybee colonies is associated with higher SHB infestations levels (Spiewok et al. 2007), an apparent key question is why reproduction is more successful in the new SHB ranges compared to Africa. 
In colonies of social bees, SHB reproduction is usually limited by defence of the workers (Neumann and Elzen 2004; Hoffmann et al. 2008; Greco et al. 2010; Halcroft et al. 2011) and only cryptic low-level reproduction may occur (Spiewok and Neumann 2006b; Torto et al. 2010). Mass reproduction (Neumann and Elzen 2004) by SHBs can result in the full structural collapse of strong colonies within 1 week (Neumann et al. 2010) and can only be observed when colony defence fails or is absent (Neumann et al. 2016). Therefore, an apparent option for SHB reproduction is associated with afterabsconding events (Hepburn et al. 1999), when colony defence is obviously absent. Both African and European honeybee colonies respond to heavy SHB infestations by absconding (Hepburn and Radloff 1998; Ellis et al. 2003a; Villa 2004; Neumann et al. 2016). Since African honeybee subspecies are more efficient in preparations for absconding (Spiewok et al. 2006) compared to European ones (Hepburn and Radloff 1998; Hepburn 2006), abandoned nests of the former may leave fewer resources behind for SHB reproduction. Brood and pollen left behind are likely to play a significant role in this regard, because proteins are required for SHB ovary activation and govern its reproduction magnitude (Ellis et al. 2002). However, abandoned honeybee nests are not only attractive for SHB. Indeed, the greater wax moth (Galleria mellonella L. Lepidoptera: Pyralidae, = GWM) is also a scavenger of honeybee colonies and is now spread globally (Paddock 1926; Morse 1975; Ellis and Munn 2005). In contrast to SHB, GWM can reproduce even in association with old, empty brood combs (Williams 1997). Therefore, GWM reproduction is less dependent on bee resources which are left behind, when compared to SHB. Nevertheless, GWMs may be competitors with SHBs for reproduction in abandoned honeybee nests, because mass reproduction of SHBS often results in the full structural collapse of the entire nest (Hepburn and Radloff 1998; Neumann et al. 2010). Moreover, ants (Hymenoptera: Formicidae) are known to be natural enemies of SHB (e.g. Pheidole megacephala in Kenya; Torto et al. 2010) and are also likely to be SHB competitors (Neumann et al. 2016), because they can forage in abandoned honeybee hives, thereby limiting SHB access to protein resources. In general, the frequency and magnitude of SHB reproduction in abandoned honeybee nests and the impact of competitors such as GWM and ants in particular have never been quantified.

Here, we systematically surveyed abandoned nests of African and European honeybees to shed light on these gaps in our knowledge. We expected that differences in absconding between honeybee subspecies might be relevant for the reproductive success of SHB, but less for GWM. If European honeybees leave more protein resources behind than African ones, SHB reproduction should occur more often and with a higher magnitude in abandoned European nests. Higher reproduction in abandoned nests would increase the numbers of SHB and the resulting pest/parasite pressure on neighbouring colonies. Since GWM larvae scavenge also on old brood combs, GWM reproduction frequency should not be affected by possible differences in preparation efficiencies between the honeybee subspecies. We also expect the presence of ants to interfere with both SHB and GWM reproductive success.

\section{MATERIALS AND METHODS}

Using standard visual screening methods (Neumann et al. 2013), the frequency and magnitude of SHB and GWM reproduction, as well as foraging by ants, were investigated in recently abandoned honeybee, A . mellifera, nests in South Africa, North America, and Australia during local nectar and pollen flows (Hepburn and Radloff 1995; Codd 1968 for the Grahamstown area). Visual screening by the same observer across all sites (S.S.) involved systematically working the colony and removing all frames that were then shaken onto a large plastic sheet or piece of plywood (ca. $1 \times 1 \mathrm{~m}$ ) such that adult beetles and ants could be seen as worker bees were smoked and flew back to the colony (Neumann et al. 2013). Wax moths were estimated on the combs and hive parts by visually looking for larvae or cocoons. On a weekly basis, all apiaries $(N=23)$ were carefully checked during daytime, weather permitting, for honeybee foraging, and hives with little or no foraging activity were opened to assess the presence of the colony. During these apiary inspections, no robbing activity (Free 1954) nor signs of robbing such as wax cappings on the entrance and ragged empty honey cells (Gary 1966) were noticed between any of the occupied hives 
with bee colonies. Otherwise, it would have obviously been required to limit robbing, i.e. via reduced entrances, as in routine beekeeping practice. In case of absconding, the entire hive was carefully inspected 2 weeks later for the presence of adult and larval SHB, GWM larvae and cocoons, and ants using standard visual screening methods described above (Neumann et al. 2013). After 2 weeks, in abandoned hives, the majority of both SHB and GWM larvae should have nearly completed their larval development (Lundie 1940; Beck 1960). This ensured the recording of successfully developed larvae, which are dependent upon the presence of honeybee products. The larger size of late larval stages also facilitates their quantification. Low numbers of larvae were individually counted, while in the case of mass reproduction (Neumann and Elzen 2004), the numbers were estimated in reference to sample sizes of 100 and 1000 individuals kept in Petri dishes that the observer used as a guide in estimating larval numbers. By using a single observer and a set of reference larval dishes, the count estimates obtained were relative to each other even given some degree of variation from the absolute number of individuals had it been possible to count all larval stages which was impossible under field conditions. Since adult GWM usually leave the colonies in the daytime (Nielsen and Brister 1977), their presence was not recorded during the survey. To check for the possibility of successive reproduction of SHB and GWM, the abandoned nests were observed for up to 12 months, but in some cases shorter periods of time due to logistical constraints of time and travel.

\subsection{South Africa}

Queenright Cape honeybee colonies $(N=$ 32), A. m. capensis, were checked at three apiaries in Grahamstown (Eastern Cape Province, South Africa) during local summer (January-March) with a nectar and pollen flow ongoing (Hepburn and Radloff 1995, especially Liliaceae, Codd 1968). Seven of the abandoned nests were left in place and screened again 12 months later to investigate the possibility of SHB and GWM reproduction in abandoned honeybee nests during a longer time period.

\subsection{USA}

In Umatilla (Florida, USA), $N=110$ queenright colonies of mixed European origin (predominantly A. m. ligustica) at 11 apiaries were observed from June to August 2004 (local summer). The nests were observed for up to 6 additional weeks after the determination of the reproductive success of SHB and GWM.

\subsection{Australia}

In the Hawkesbury Area (NSW, Australia), $N=$ 90 queenright colonies of mixed European origin (predominantly A. $m$. ligustica) were observed at nine apiaries from October to November 2005 (local spring), with good weather and nectar and pollen flow ongoing. After the determination of the reproductive success of SHB and GWM, the nests were observed for up to 2 additional weeks.

\subsection{Comparison of small hive beetle and greater wax moth reproduction and foraging by ants}

The frequencies of successful SHB and GWM reproduction and the presence of foraging ants were analysed for differences between the three different regions using Pearson's $\chi^{2}$ tests and Fisher's exact tests (Bonferroni adjusted level of significance: $P=0.017$ ). Analyses for differences in the magnitudes of the reproductive success of SHB and GWM and in the numbers of foraging ants between the different regions were done with Pearson's $\chi^{2}$ test (Bonferroni adjusted level of significance for post hoc comparisons: $P=$ 0.017). To compare the frequencies of reproduction between SHB and GWM, the McNemar test was used and the Wilcoxon-matched pair test was used for the magnitudes of reproduction. Correlations between the frequency or magnitude of SHB and GWM reproduction and the presence or numbers of ants were tested for significance using Kendall's tau-b (Quinn and Keough 2002). This is a nonparametric measure of correlation for ordinal or ranked variables that takes ties into account (Bonferroni adjusted level of significance: $P=0.017)$. Tests were run using Statistica ( (StatSoft 2010). 


\subsection{Preparation efficacy of colonies for absconding}

The areas of abandoned stores and brood of the absconded colonies $(N=9)$ in Australia were evaluated using the standard Liebefelder method (Gerig 1983; Imdorf et al. 1987). The results were compared with respective data for Cape honeybee colonies (Spiewok et al. 2006) using MannWhitney $U$ tests to test for potential differences between African and European subspecies in their preparation efficacy for absconding. Simple correlations were run between the amount of abandoned protein sources (brood and pollen stores) as well as the carbohydrate source (honey) and the magnitude of SHB reproduction (Bonferroni adjusted level of significance: $P=0.017$ ).

\section{RESULTS}

\subsection{South Africa}

A total of 14 colonies absconded within the observation period (incl. $N=7$ from Spiewok et al. 2006; Table I). The very small amounts of abandoned brood and honey stores (Table II) were subsequently robbed by workers from adjacent honeybee colonies and/or foraged by ants. With one exception, adult SHBs were present in every abandoned nest, but all of them left within the following 4 days. No reproduction of SHB was found in any of the abandoned nests within 2 weeks after absconding, while GWM successfully reproduced in low numbers $(<100$ larvae/ nest) in $28.6 \%$ of them (Table I). However, several hundred cocoons of GWM pupae were collected from all seven nests, which were observed for 12 months, thereby increasing the frequency of GWM reproduction to $78.6 \%$ of all nests. The combs were then completely gone in all colonies. In one hive, a new bee swarm settled in and in another one, an African Pygmy Dormouse, Graphiurus murinus Smuts (Rodentia: Gliridae), had built its nest.

\subsection{USA}

A total number of 12 abandoned/absconded honeybee nests were found (Table I). Adult SHBs were present in all nests and successfully reproduced in $58.3 \%$ of them, while GWM reproduced in $75 \%$ of the nests. Moreover, two colonies with SHB mass reproduction (> 1000 larvae) were subsequently occupied by GWM larvae $(N>1000)$ during the 6 additional observation weeks, when most SHB larvae had already left the nest to pupate. This increased the frequency of nests with successful GWM reproduction to $91.7 \%$. In two other colonies, the honeybees did not abscond, although several combs were destroyed by GWM larvae.

\subsection{Australia}

Seven abandoned nests were found, all housing adult SHBs (Table I). SHB reproduced in $71.4 \%$ and GWM in $42.9 \%$ of the nests. In two further colonies, the bees remained in the upper hive boxes although the combs of the lower boxes were already destroyed by a combination of SHB and GWM larvae.

\subsection{Abandoned brood and stores}

Compared to Cape honeybee colonies (Spiewok et al. 2006), the European colonies left behind significantly more brood (Mann-Whitney $U$ test: $U=$ 17.5, $P=0.044)$, honey $(U=2.0, P<0.001)$ and pollen stores $(U=10.0, P=0.005$; Table II).

\subsection{Correlation between abandoned food sources and small hive beetle reproduction}

The magnitude of SHB reproduction was significantly correlated with the amount of abandoned protein sources, but not of carbohydrates (Spearman rank correlation: pollen $-r_{\mathrm{s}}=0.89, t_{5}=4.27, P=$ 0.008 ; brood $-r_{\mathrm{s}}=0.85, t_{5}=3.68, P=0.014$; honey $\left.-r_{\mathrm{s}}=0.61, t_{5}=1.73, P=0.143\right)$.

\subsection{Comparison of reproductive success of small hive beetles and greater wax moths between abandoned European and African honeybee nests}

The frequency $(F r)$ as well as the magnitude $(M a)$ of SHB reproduction was significantly different among the three countries $\left(F r: \chi_{2}^{2}=14.22\right.$, $P<0.001 ;$ Ma: $\left.\chi_{6}^{2}=17.59, P=0.007\right)$. SHB did 
Table I. Reproduction of small hive beetles and greater wax moth as well as foraging by ants in abandoned honeybee hives in Africa, North America and Australia within 2 weeks after absconding (a SHB = adult small hive beetle; 1 SHB $=$ larval small hive beetle, GWM $=$ wax moth larvae; $-=0 ;+=<100 ;++=100-1000 ;+++=>1000$ )

\begin{tabular}{|c|c|c|c|c|c|c|c|c|c|c|c|c|}
\hline \multirow[t]{2}{*}{ Colony } & \multicolumn{4}{|c|}{ South Africa } & \multicolumn{4}{|c|}{ USA } & \multicolumn{4}{|c|}{ Australia } \\
\hline & $\begin{array}{c}\mathrm{a} \\
\mathrm{SHB}\end{array}$ & $\begin{array}{c}1 \\
\text { SHB }\end{array}$ & GWM & Ants & $\begin{array}{c}\mathrm{a} \\
\text { SHB }\end{array}$ & $\begin{array}{c}1 \\
\text { SHB }\end{array}$ & GWM & Ants & $\begin{array}{c}\mathrm{a} \\
\text { SHB }\end{array}$ & $\begin{array}{c}1 \\
\text { SHB }\end{array}$ & GWM & Ants \\
\hline 1 & + & - & + & + & ++ & +++ & $-{ }^{\mathrm{b}}$ & - & +++ & +++ & ++ & - \\
\hline 2 & + & - & + & - & ++ & +++ & $-{ }^{\mathrm{b}}$ & - & ++ & +++ & ++ & - \\
\hline 3 & + & - & + & - & ++ & +++ & +++ & - & ++ & +++ & - & - \\
\hline 4 & + & - & + & - & ++ & +++ & - & - & ++ & ++ & - & + \\
\hline 5 & + & - & $-^{\mathrm{a}}$ & - & + & + & ++ & + & ++ & + & - & - \\
\hline 6 & + & - & $--^{\mathrm{a}}$ & - & + & + & ++ & - & + & - & + & - \\
\hline 7 & + & - & $-{ }^{\mathrm{a}}$ & - & + & + & ++ & - & + & - & - & - \\
\hline 8 & - & - & $-{ }^{\mathrm{a}}$ & + & + & - & ++ & - & & & & \\
\hline 9 & + & - & $-{ }^{1}$ & - & + & - & ++ & + & & & & \\
\hline 10 & + & - & $-{ }^{1}$ & - & + & - & + & + & & & & \\
\hline 11 & + & - & $-{ }^{1}$ & - & + & - & + & - & & & & \\
\hline 12 & + & - & - & ++ & + & - & + & ++ & & & & \\
\hline 13 & + & - & - & + & & & & & & & & \\
\hline 14 & + & - & - & + & & & & & & & & \\
\hline
\end{tabular}

${ }^{\text {a }}$ Twelve months after absconding +++ WM cocoons were found in these nests

${ }^{\mathrm{b}}$ First occupied by SHB larvae, then by $+++\mathrm{WM}$ larvae

Table II. Abandoned stores by absconding European and Cape honeybee colonies (A. m. capensis). The estimated areas of abandoned pollen and honey stores and brood are shown

\begin{tabular}{|c|c|c|c|c|c|c|}
\hline \multirow[t]{2}{*}{ Colony $^{\mathrm{a}}$} & \multicolumn{2}{|c|}{$\operatorname{Brood}\left(\mathrm{dm}^{2}\right)$} & \multicolumn{2}{|c|}{ Honey $\left(\mathrm{dm}^{2}\right)$} & \multicolumn{2}{|c|}{ Pollen $\left(\mathrm{dm}^{2}\right)$} \\
\hline & European & A. $m$. capensis $^{\text {b }}$ & European & A. m. capensis ${ }^{\mathrm{b}}$ & European & A. m. capensis ${ }^{\mathrm{b}}$ \\
\hline 1 & 9.63 & 0 & 25.68 & 2.75 & 6.42 & 0 \\
\hline 2 & 6.42 & 0 & 81.32 & 0 & 4.28 & 0 \\
\hline 3 & 3.21 & 1.10 & 6.42 & 0 & 6.42 & 0.55 \\
\hline 4 & 0 & 0 & 5.35 & 0 & 3.21 & 0 \\
\hline 5 & 1.07 & 0.55 & 2.14 & 0 & 0 & 0 \\
\hline 6 & 0 & 0 & 12.84 & 0 & 2.14 & 0 \\
\hline 7 & 0 & 0 & 2.14 & 0 & 0 & 0 \\
\hline 8 & - & 0 & - & 0 & - & 0 \\
\hline 9 & - & 0 & - & 0 & - & 0 \\
\hline $\begin{array}{l}\text { Median } \\
\text { (1st; 3rd quartile) }\end{array}$ & $\begin{array}{l}1.07 \\
(0 ; 4.8)\end{array}$ & $\begin{array}{l}0 \\
(0 ; 0)\end{array}$ & $\begin{array}{l}6.42 \\
(3.8 ; 19.3)\end{array}$ & $\begin{array}{l}0 \\
(0 ; 0)\end{array}$ & $\begin{array}{l}3.21 \\
(1.1 ; 5.4)\end{array}$ & $\begin{array}{l}0 \\
(0 ; 0)\end{array}$ \\
\hline
\end{tabular}

${ }^{\text {a }}$ Colony numbers are corresponding to those in Table I (South Africa)

${ }^{\mathrm{b}}$ Data from Spiewok et al. (2006) 
not reproduce in abandoned African honeybee nests, but in $58.3 \%$ of the ones in the USA (Fisher exact test: $P=0.001)$ and in $71.4 \%$ of the ones in Australia $(P=0.001)$. The frequency of reproduction was not significantly different between the USA and Australia $(P=0.656)$. Likewise, the magnitude of SHB reproduction was significantly lower in African nests compared to European ones in the USA $\left(\chi_{3}^{2}=11.18, P=0.011\right)$ and Australia $\left(\chi_{3}^{2}=13.13, P=0.004\right)$, while there was no significant difference between the latter ones $\left(\chi_{3}^{2}=2.27\right.$, $P=0.518)$. In contrast, no significant differences in the frequency or magnitude of GWM reproduction were detected among the three regions $\left(F r: \chi_{2}^{2}=\right.$ 5.69, $\left.P=0.058 ; M a: \chi_{6}{ }_{6}=10.42, P=0.108\right)$.

\subsection{Comparison of reproductive success between small hive beetles and greater wax moths in abandoned nests}

Neither the frequency nor the magnitude of reproduction differed significantly between SHB and GWM in abandoned European honeybee nests in the USA $\left(F r\right.$ : McNemar test- $\chi^{2}{ }_{1}=$ 2.25, $P=0.134 ; M a$ : Wilcoxon-matched pair test $-T=30.0, P=0.790)$. However, if one includes the two cases of GWM reproduction within the 6 additional observation weeks, GWM reproduced significantly more often than SHB in the USA, but the magnitude was still not significantly different between the two species $(F r$ : $\left.\chi_{1}^{2}=4.17, P=0.041 ; M a: T=9.0, P=0.110\right)$. No significant differences between SHB and GWM reproduction were found in the Australian nests $\left(F r: \chi_{1}{ }_{1}=0.06, P=0.625 ; M a: T=2.5\right.$, $P=0.093)$. Due to the lack of variance in the frequency of SHB reproduction, a respective comparison was not possible for Africa. No significant difference was found in the magnitude of reproduction between SHB and GWM in African nests after 2 weeks $(T=0.0, P=0.068)$.

SHB and GWM offspring developed simultaneously in $31.6 \%$ of the European nests in USA and Australia. Nevertheless, in all but one case (USA: colony 3 ), the larvae of one species outnumbered the other one. A tendency for a negative relationship between the frequency of SHB and GWM reproduction, but not for the magnitude, was found $(F r: \operatorname{tau}=0.49, P=$ 0.027; $M a:$ tau $=0.14, P=0.513)$.

Nests with SHB mass reproduction showed the typical signs of damage such as a characteristic smell, slimy combs and fermented honey (Lundie 1940), while those with no or low numbers of SHB larvae $(<100)$ were predominantly dry. In contrast, large numbers of GWM larvae were found in moist as well as in dry nests. In the only nest with simultaneous SHB and GWM mass reproduction (>1000 larvae each), GWM larvae were predominantly on the dry combs while SHB larvae tended to roam on the slimy moist combs.

\subsection{Impact of ants}

The presence of foraging ants in nests varied from $14.3 \%$ in Australia to $35.7 \%$ in Africa, but neither the frequency nor the numbers $(\mathrm{Nu})$ were significantly different among the three regions (Fr: $\chi_{2}^{2}=1.10, P=0.578 ; N u: \chi^{2}{ }_{4}=1.28, P=$ 0.864, Table I).

Species found in the nests were Pheidole megacephala in South Africa, Camponotus floridanus in Florida and meat ants (Iridomyrmex spp. ) in Australia. There were tendencies towards negative correlations between the frequency and the magnitude of SHB reproduction and the presence or numbers of ants (Fr: tau $=-0.48, P=$ 0.030; Nu: $\operatorname{tau}=-0.52, P=0.019)$. There was no significant correlation between the frequency of GWM and ants or the magnitude of GWM reproduction and the numbers of ants $(F r:$ tau $=$ $0.41, P=0.065 ; N u:$ tau $=-0.05, P=0.829)$.

\section{DISCUSSION}

The data show striking differences by two orders of magnitude in SHB reproduction between abandoned nests of African and European honeybee subspecies, but not for GWM. Since the impact of competing ants and GWM was not significant, the positive correlation between abandoned protein sources and SHB reproduction suggests that the less efficient preparation for absconding of European honeybees is one key factor explaining higher SHB population sizes, and thus damage (Spiewok et al. 2007), in its new distribution ranges. 
Seasonal migration (Schneider and McNally 1992; Neumann et al. 2000) is unlikely to explain the observed absconding events, because the survey was conducted during local nectar and pollen flows. African colonies can quickly react with absconding to even minor disturbance (Hepburn and Radloff 1998), including beekeeping manipulations (Spiewok et al. 2006). In sharp contrast, European honeybee subspecies are very reluctant to abscond (Butler 1967; Winston 1987) and so-called hunger swarms are very rare (Zander and Weiss 1964). The exact causes for the absconding events in this study remain unclear, but SHBs are known to induce such events in African (Fletcher 1975, 1976; Hepburn and Radloff 1998) and even in European honeybee colonies (Ellis et al. 2003b; Villa 2004; Neumann et al. 2016). In any case, absconding European colonies left significantly more stores and brood behind than African ones. What are potential reasons for these differences?

Robbing between occupied hives was not noticed during routine beekeeping inspections of the test apiaries and is therefore unlikely to have impacted the amount of resources prior to absconding. In any case, robbing is directed towards honey and not pollen (Free 1954; Gary 1966; Winston 1987). Recent research demonstrates that bees utilise fresh over stored pollen (Carroll et al. 2017), but pollen, fresh nor stored as beebread, has never been reported to be removed during robbing as worker bees have no mechanism to efficiently move pollen as they do when using a full crop to transport honey. So, even if there were any differences in robbing, abandoned pollen stores were almost certainly not affected by robbing. Finally, we are not aware of any report that robbing honeybees have ever taken brood. Despite this, brood and pollen could have been taken by ants foraging in the empty hives. Camponotus floridanus was found in four colonies in Florida (USA), but data were not evaluated for abandoned stores and brood left behind. In South Africa, ants were found in two hives and identified as Pheidole megacephala. Similarly, meat ants (Iridomyrmex spp.) were found in one hive in Australia, but neither the frequency nor the magnitude of ant foraging was strikingly different between Africa and Australia. It is obviously impossible to exclude that ants may have removed stores and brood prior to our inspections, but we regard this is a systematic conservative error over both locations. In conclusion, it is unlikely that either conspecific robbing or foraging by ants can explain the striking differences between the pollen stores and brood left behind by absconding African and European honeybee colonies. Instead, it is most likely that African honeybees were more efficient in their preparations for absconding (Spiewok et al. 2006), which appears to be adaptive in light of the general higher mobility of African honeybee colonies (Hepburn and Radloff 1998).

The ultimate reasons for this apparent difference between African and European honeybee subspecies are most likely ecological constraints on European ones, leading to high home fidelity to ensure winter survival. Temperate honeybee subspecies are reluctant to abscond at all (Butler 1967; Winston 1987), which is illustrated by those colonies remaining in their nests although considerable parts were already destroyed by either SHB (Figure 1) or GWM larvae. A reluctance to abscond is very

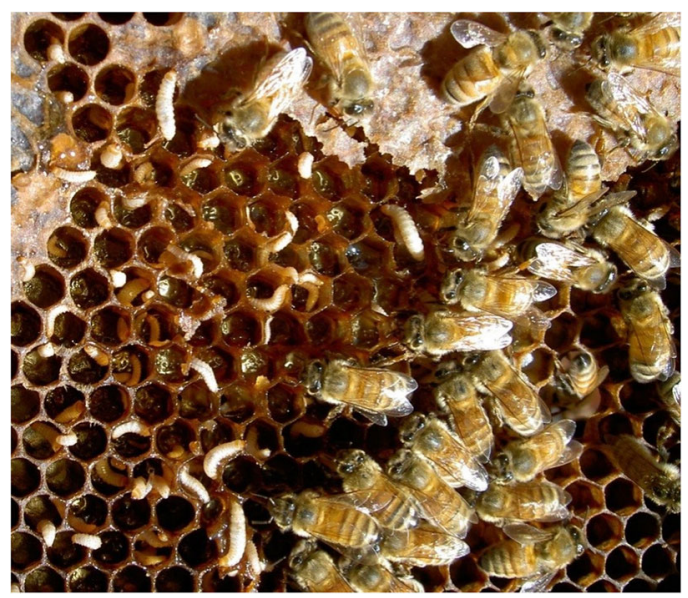

Figure 1 Small hive beetle mass reproduction in a colony of European-derived honeybees in Australia. The bees are still present despite the presence of $>$ 1000 beetle larvae and resulting damage to the colony, which still has ample stores (Picture by P.N.). 
likely to negatively influence the efficiency of the respective preparations (Spiewok et al. 2006). Furthermore, it is well known that colonies of European honeybee subspecies tend to be larger and have more food stores compared to those of the African ones (Hepburn and Radloff 1998). Therefore, European honeybees probably have to consume more stores per capita than African ones. Assuming equal absconding efficiency of both African and European honeybee subspecies (which is not the case, Spiewok et al. 2006), it seems inevitable that European colonies will have to leave more brood and food behind. For example, this might just exceed the workers' physiological capability to uptake food and to store it in the form of body fat. It appears as if the combination of less efficient preparations together with larger colony sizes of European honeybee subspecies governs the amount of brood and pollen stores left behind after absconding.

Since the amount of protein sources positively correlates with the magnitude of SHB reproduction, the higher quantity of abandoned pollen stores and brood in absconded European colonies is associated with an increase in the frequency and magnitude of SHB reproduction. SHB reproduction might already have started prior to the actual absconding event. Indeed, the preparation period for absconding is a critical time window because stores are still available as a breeding substrate, but colony defensiveness is reduced, e.g. African honeybee colonies undergoing preparation for absconding did not completely remove SHB offspring (Spiewok and Neumann 2006c). Therefore, prolonged preparations in European honeybee subspecies due to a lower efficiency and a higher amount of stores appear to favour SHB reproduction. On the contrary, the high preparation efficiency connected to the proneness for absconding in African colonies leads to a lack of protein resources in deserted African honeybee nests (Spiewok et al. 2006). This seems to limit or even entirely prevent SHB reproduction after prepared absconding. Consequently, SHB reproduction in abandoned African honeybee nests appears to be restricted to low-level (Spiewok and Neumann 2006b) and non-prepared absconding events, when colonies abandon eggs, brood and food stores altogether (Gough 1928; Lundie 1940; Schmolke 1974; Hepburn and Radloff 1998).

In contrast to SHB, the reproductive success of GWM was independent of honeybee subspecies, probably because their larvae can develop even on old, empty combs (Paddock 1926; Milium 1935). Even though more protein resources may also be beneficial for GWM, they apparently depend less on abandoned stores than SHB. In Africa, GWM reproduced more often in deserted nests compared to SHB, which cannot reproduce on empty combs (Ellis et al. 2002). Although both larval GWM and SHB occurred simultaneously in the same colony, there were no significant effects on each other. This is in line with Schmolke (1974), who reported that GWM and SHB can breed simultaneously, but often occur alone in a nest.

Even though ants can drive an entire honeybee colony out of their hive (Fell 1997) and $P$. megacephala is known to be a predator of SHB larvae (Torto et al. 2010), there were no significant effect of ant presences on either SHB or GWM reproduction. Since SHB larvae are often covered with a slimy coating derived from fermenting honey (Neumann and Härtel 2004), this coating may protect them against ant predation as long as some honey is left behind in the nests. Similarly, GWM offspring may be protected against ant predation due to the silk webbing the larvae produce. Since foraging ants and GWM were present in each study area and had no significant impact on SHB reproduction, at least these investigated competitors seem unlikely to explain the differences in SHB reproductive success between Africa and its new ranges. We recommend that future studies are conducted under the same environments to confirm or challenge the conclusions of this study, e.g. analysing the same parameters in equalised European and Africanized honeybee colonies studied in the same environment in the Americas.

The present data suggest that adaptations to temperate climates most likely limit the full 
behavioural defensive repertoire of European honeybee colonies against a high SHB infestation load. Indeed, an absconding swarm late in the season has virtually zero chances to survive winter time in the temperate regions. Mass food hoarding and low absconding rates are most likely even further expressed in European subspecies due to a long history of breeding for traits beneficial to apiculture, which is virtually absent in Africa. Therefore, European honeybees are more likely to stay in their nests even though they cannot cope with a high SHB infestation anymore (Figure 1).

In conclusion, the data suggest a weak impact of the investigated competitors on SHB reproductive success. Instead, the more frequent SHB mass reproduction in abandoned European honeybee nests seems to be a key factor for the higher SHB population build-up in the invasive ranges with resulting damage to colonies (Spiewok et al. 2007). Even though quantitative differences between African and European honeybee subspecies in a range of other behaviours may also contribute (Ellis et al. 2003b; Ellis et al. 2004; Neumann and Elzen 2004), the sheer number of SHB resulting from reproduction in abandoned honeybee nests alone appears to be sufficient to explain the differential pest impact and invasion success. Therefore, ecological constraints imposed on temperate honeybee subspecies limiting their colony mobility appear to facilitate the invasion success of SHB, regardless of other biotic or abiotic factors.

\section{ACKNOWLEDGEMENTS}

P.N. is most grateful to H Randall Hepburn for initiating his fascination for small hive beetles and this research paper is dedicated in his memory. The authors wish to thank two anonymous referees for constructive comments, Michael Duncan (Western Sydney University) and David Westervelt (FD Florida), for logistical support as well as local beekeepers for access to their colonies. Special thanks to Ulrike Epperlein and Nelles Ruppert for the technical support in the field.

\section{AUTHOR CONTRIBUTIONS}

P.N., S.S. and H.R.H. conceived the study; JP, SR and RS provided field sites and experimental support; S.S. conducted the experiments and analysed the data; P.N. and S.S. wrote the manuscript and all authors reviewed drafts of the manuscript.

\section{FUNDING INFORMATION}

Financial support was granted to P.N. by the German Federal Ministry for Food, Agriculture and Consumer Protection through the Federal Agency for Agriculture and Food, a visiting professorship at Rhodes University and a visiting fellowship at Western Sydney University.

\section{OPEN ACCESS}

This article is distributed under the terms of the Creative Commons Attribution 4.0 International License (http://creativecommons.org/licenses/by/4.0/), which permits unrestricted use, distribution, and reproduction in any medium, provided you give appropriate credit to the original author(s) and the source, provide a link to the Creative Commons license, and indicate if changes were made.

Les différences de désertion entre les sous-espèces africaines et européennes d'abeilles mellifères facilitent le succès de l'invasion des petits coléoptères des ruches.

Fourmis / Apis mellifera / Aethina tumida / Galleria mellonella / petit coléoptère des ruches.

Unterschiede im Absconding-Verhalten zwischen afrikanischen und europäischen Honigbienen erleichtern den Invasionserfolg des Kleinen Beutenkäfers.

Ameisen/ Apis mellifera / Aethina tumida / Galleria mellonella / Kleiner Beutenkäfer.

\section{REFERENCES}

Beck, S.D. (1960) Growth and development if the greater wax moth Galleria mellonella (Lepidoptera: Galleriidae). Trans. Wisconsin Acad. Sci, Arts Letters. 49, 137-148. 
Buchholz S., Schäfer M.O., Spiewok S., Pettis J.S., Duncan M., Ritter W., SpoonerHart R., Neumann P. (2008) Alternative food sources of Aethina tumida (Coleoptera: Nitidulidae), J. Apic. Res. Bee World 47(3), 201-208.

Butler, C.G. (1967) The world of the honeybee. Collins, London.

Carroll M.J., Brown N., Goodall C., Downs A.M., Sheenan T.H., Anderson K.E. (2017) Honey bees preferentially consume freshly-stored pollen. PLoS ONE 12(4): e0175933. https://doi.org/10.1371/journal.pone.0175933

Codd, L.E. (1968) The South African Species of Kniphofia (Liliaceae). Bothalia; Vol 9, No 3/4: 363-513. doi: https://doi.org/10.4102/abc.v9i3/4.1790

Ellis J.D., Munn P.A. (2005) The worldwide health status of honey bees. Bee World 86(4), 88-101.

Ellis J.D., Neumann P., Hepburn H.R., Elzen P.J. (2002) Longevity and reproductive success of Aethina tumida (Coleoptera: Nitidulidae) fed different natural diets, J. Econom. Entomol. 95, 902-907.

Ellis, J.D., Hepburn, R., Delaplane, K.S., Elzen, P.J. (2003a) A scientific note on small hive beetle (Aethina tumida) oviposition and behaviour during European (Apis mellifera) honey bee clustering and absconding events. Journal of Apicultural Research 42, 47-48.

Ellis, J.D., Hepburn, H.R., Delaplane, K., Neumann, P., Elzen, P.J. (2003b) The effects of adult small hive beetles, Aethina tumida (Coleoptera: Nitidulidae), on nests and flight activity of Cape and European honey bees (Apis mellifera ). Apidologie, 34, 399-408.

Ellis, J.D., Delaplane, K.S., Richards, C.S., Hepburn, R., Berry, J.A., Elzen, P.J. (2004) Hygienic behaviour of Cape and European Apis mellifera (Hymenoptera: Apidae) toward Aethina tumida (Coleoptera: Nitidulidae) eggs oviposited in sealed brood cells Ann. Entomol. Soc. Am., 97, 860-864.

Fell, R.D. (1997) Insects: Hymenoptera (ants, wasps, and bees). In: R.A. Morse and K. Flottum (Eds.), Honey bee pests, predators, and diseases. $3^{\text {rd }}$ ed. A.I Root Company, Medina, pp. 163-200.

Fletcher, D.J.C. (1975) New perspectives in the causes of absconding in the African bee (Apis mellifera adansonii L.) Part I South African Bee Journal, 47, 11-14.

Fletcher, D.J.C. (1976) New perspectives in the causes of absconding in the African bee (Apis mellifera adansonii L. ) Part II. South Afr. Bee J., 48, 6-9.

Free, J. B. (1954) The behaviour of robber honeybees. Behaviour, 7, 233-240.

Gary, N.E. (1966) Robbing behavior in the honey bee. Amer. Bee J., 106, 446-448.

Gerig, L. (1983) Lehrgang zur Erfassung der Volksstärke. Schw. Bienen-Ztg. 106, 199204.

Gough, L.H. (1928) Apistischer Brief aus Südafrika. Der Bienenvater, 60, 30-32.

Greco M. K., Hoffmann D., Dollin A., Duncan M., Spooner-Hart R., Neumann P. (2010) The alternative Pharaoh approach: stingless bees mummify beetle parasites alive, Naturwissenschaften 97(3), 319-323.
Halcroft M., Spooner-Hart R., Neumann P. (2011) Behavioral defense strategies of the stingless bee, Austroplebeia australis, against the small hive beetle, Aethina tumida, Insectes Soc. 58(2), 245-253.

Hepburn, H.R. (2006) Absconding, migration and swarming in honeybees: an ecological and evolutionary perspective. Life Cycles in Social Insects: Behaviour, Ecology and Evolution (ed. by V.E. Kipyatkov), pp. 121-135. St. Petersburg University Press, St. Petersburg.

Hepburn, H.R., Radloff, S.E. (1995) First approximation to a phenology of the honeybees (Apis mellifera) and flora of Africa. Oecologia 101: 265-273.

Hepburn H.R., Radloff S.E. (1998) Honeybees of Africa. Springer Verlag, Berlin, Heidelberg, New York.

Hepburn, H.R., Reece, S., Neumann, P., Moritz, R.F.A., Radloff, S.E. (1999) Absconding in honeybees (Apis mellifera) in relation to queen status and mode of reproduction, Insectes Soc. 46, 323-326.

Hoffmann D., Pettis J.S., Neumann P. (2008) Potential host shift of the small hive beetle (Aethina tumida) to bumblebee colonies (Bombus impatiens). Insectes Soc. 55, 153-162.

Imdorf, A., Bühlmann, G., Gerig, L., Kilchenmann, V., Wille, H. (1987) Überprüfung der Schätzmethode zur Ermittlung der Brutfläche und Anzahl Arbeiterinnen in freifliegenden Bienenvölkern. Apidologie, 18, 137-146.

Lundie A.E. (1940) The small hive beetle Aethina tumida, Science Bulletin 220, Dep. Agr. Forestry, Government Printer, Pretoria, South Africa.

Milium, V.G. (1935) Lesser vs. greater wax-moth. Gleanings Bee Culture, 63, 662-666.

Morse, R.A. (1975) Bees and beekeeping. Ithaca, New York: Cornell University Press

Neumann P., Ellis J.D. (2008) The small hive beetle (Aethina tumida Murray, Coleoptera: Nitidulidae): distribution, biology and control of an invasive species. J. Apic. Res. Bee World 47(3), 180-183.

Neumann P., Elzen P.J. (2004) The biology of the small hive beetle (Aethina tumida, Coleoptera: Nitidulidae): Gaps in our knowledge of an invasive species, Apidologie 35, 229-247.

Neumann P., Härtel S. (2004) Removal of small hive beetle (Aethina tumida) eggs and larvae by African honeybee colonies (Apis mellifera scutellata), Apidologie 35, 31-36.

Neumann P, Koeniger N, Koeniger G, Tingek S, Kryger P, Moritz RFA (2000) Home site fidelity in migratory honeybees. Nature 406: 474-475.

Neumann P., Hoffmann D., Duncan M., Spooner-Hart R. (2010) High and rapid infestation of isolated commercial honey bee colonies with small hive beetles in Australia, J. Apic. Res. Bee World 49(4), 343-344.

Neumann P., Evans J.D., Pettis J.S., Pirk C.W.W., Schäfer M.O., Tanner G., Ellis J.D. 2013 Standard methods for small hive beetle research. J. Apic. Res. 52(4), 1-32.

Neumann P, Pettis JS, Schäfer MO (2016) Quo vadis Aethina tumida? Biology and control of small hive 
beetles. Apidologie 47(3), 427-466. https://doi. org/10.1007/s13592016-0426-x.

Nielsen, R.A. Brister, C.D. (1977) Greater wax moth: Adult behavior. Ann. Entomol. Soc. Am. 70, 101-103.

Paddock, F.B. (1926) The chronological distribution of the bee moth Journal of Economical Entomology, 19, 136-141.

Peña W.L., Carballo L.F., Lorenzo J.D. (2014) Reporte de Aethina tumida Murray (Coleoptera, Nitidulidae) en colonias de la abeja sin aguijón Melipona beecheii Bennett de Matanzas y Mayabeque, Revista de Salud Anim. 36(3), 201-204.

Pirk C.W.W., Yusuf A.A. (2017) A small hive beetle lesson from South Africa. In: N.L. Carreck (Ed.) The small hive beetle in Europe. International Bee Research Association; Groombridge, $U K$, in press .

Quinn, G.P., Keough, M.J. (2002) Experimental Design and Data Analysis for Biologists. University Press, Cambridge.

Schmolke M.D. (1974) A study of Aethina tumida: the small Hive Beetle, Project Report, University of Rhodesia, pp. 178.

Schneider, S.S., McNally, L.C. (1992) Factors influencing seasonal absconding in colonies of the African honey bee, Apis mellifera scutellata . Ins. Sociaux, 39, 402-423.

Spiewok S., Neumann P. (2006a) Infestation of commercial bumblebee (Bombus impatiens) field colonies by small hive beetles (Aethina tumida), Ecol. Entomol. $31,623-628$.

Spiewok S., Neumann P. (2006b) Cryptic low-level reproduction of small hive beetles in honeybee colonies, $\mathrm{J}$. Apic. Res. 45(1), 47-48.

Spiewok S., Neumann P. (2006c) The impact of recent queenloss and colony phenotype on the removal of
Small hive beetle (Aethina tumida Murray) eggs and larvae by African honeybee colonies (Apis mellifera capensis Esch.), J. Insect Behav. 19(5), 601-611.

Spiewok S., Neumann P., Hepburn H.R. (2006) Preparation for disturbance-induced absconding of Cape honeybee colonies (Apis mellifera capensis Esch.), Insectes Soc. 53, 27-31.

Spiewok S., Pettis J.S., Duncan M., Spooner-Hart R., Westervelt D., Neumann P. (2007) Small hive beetle, Aethina tumida, populations I: Infestation levels of honeybee colonies, apiaries and regions, Apidologie 38(6) 595-605.

Spooner-Hart, R., Annand, N., Duncan, M. (2017). The small hive beetle in Australia. In: N.L. Carreck (Ed.) The small hive beetle in Europe. International Bee Research Association; Groombridge, UK, in press.

StatSoft, Inc. (2010) STATISTICA, version 10.0, www. statsoft.com.

Torto B., Fombong A.T., Arbogast R.T., Teal P.E. (2010) Monitoring Aethina tumida (Coleoptera: Nitidulidae) with baited bottom board traps: occurrence and seasonal abundance in honey bee colonies in Kenya, Environ. Entomol. 39(6), 1731-1736.

Villa J.D. (2004) Swarming behaviour of honey bees (Hymenoptera: Apidae) in Southeastern Louisiana, Ann. Entomol. Soc. Am. 97(1), 111-116.

Williams, J.L. (1997) Insects: Lepidoptera (moths). In: R.A. Morse and K. Flottum (Eds.) Honey bee pests, predators, and diseases. $3^{\text {rd }}$ ed. A.I Root Company, Medina, pp. 119-142.

Winston, M.L. (1987) The biology of the honey bee. Harvard University Press, Cambridge.

Zander, E., Weiss, K. (1964) Das Leben der Biene. Ulmer Verlag Stuttgart. 6. Auflage. 189 pp. 